\title{
Money Demand Features in CEE Countries
}

\author{
Valentina-Ioana MERA \\ Faculty of Economics and Business Administration, \\ Babeș-Bolyai University, Cluj-Napoca, Romania \\ valentina.mera@econ.ubbcluj.ro
}

The existence of a stable relationship between money demand and its determinants is important for the efficiency of monetary policy. In this paper we carried a preliminary analysis on the variables that can influence money demand in five Central and Eastern European countries (Bulgaria, Czech Republic, Hungary, Poland and Romania) in order to determine which characteristics define the evolution of money demand and its determinants, and how volatile they are. The results indicate a number of similarities in terms of monetary development and also suggest that some additional variables that may influence money demand in this specific sample.

Keywords: Money Demand, Inflation, Exchange Rates, CEE Countries

\section{1} Introduction

Money demand is an important topic for economic policymakers, as their aim is to select the monetary policy instruments that are most suitable for an efficient monetary policy. In order to use monetary aggregates as an instrument for the conduct of monetary policy, a stable and predictable relationship between money demand and its determinants is required [1]. The capability of understanding monetary developments can make the difference between an efficient monetary policy and an uncertain future evolution of the macroeconomic variables. For testing the stability of the relationship between money and the evolution of prices, money demand is linked to other macroeconomic variables such as: income or interest rates.

Macroeconomic stability is one of the main goals of monetary authorities, as they direct their effort towards a global objective of economic growth and development. The complexity of the economy seen at a national or interregional level, brings a number of challenges for policymakers in order to specify a model for money demand which best fits each individual economy. Therefore, a high number of factors should be taken into consideration, be they macroeconomic variables or country-specific characteristics.

In this context, the evolution of the monetary aggregates in transition economies takes on a new meaning, as their economies experienced structural changes over time. Features like the persistence of some structural shocks or the lack of strong institutional framework may be responsible for unforeseen fluctuations in the evolution of the monetary aggregates. Among the main causes that can make the development of the monetary aggregates different from advanced economies are [2, pp. 4-5]: financial underdevelopment, poor fiscal management, the lack of independence of the monetary authority or the predisposition of being more receptive to foreign shocks. Therefore we try to assess the impact of each determinant of money demand, by integrating this evolution in the context of the stylized facts that characterize their economy. The main question that supports this analysis is which dimension of the demand for money has the main impact, so if the liquidity or the risk associated is the driven factor of its evolution.

The aim of this paper is to make a preliminary analysis of the variables that influence the demand for money in Central and Eastern European (CEE) countries. We choose to include in our sample only countries that are members of the European Union (since 2004: Czech Republic, Hungary, Poland and since 2007: Bulgaria and Romania), but have not already adopted the single currency. The selection of countries is also dictated by data availability, as countries like Slovak Republic or Slovenia entered into the euro area in January 2009 and, 
respectively January 2007 , and therefore information about the demand for money in their local currency is not available anymore. The remaining of the paper is organised as follows. In Section 2 are presented some studies that have approached the topic of money demand in Central and Eastern European countries and it is formulated the theoretical framework of the money demand specification. In sections 3 and 4 it is made a detailed description of the variables used in the traditional money demand functions, with special focus on the specific features of CEE countries' development. Concluding remarks are presented in section 5 .

\section{Literature Review on Money Demand in CEE countries}

In spite of the existence of an extensive literature on money demand and its determinants, from an empirical point of view, there are still countries that remain uncovered in terms of long run money demand modelling. The reason is sometimes dictated by data availability, as it is the case of the countries from CEE, because in the majority of these economies, data on monetary aggregates become available only few years after 1990. The different development pace and also the differences in monetary policy implementation makes difficult the attempt to treat these countries as a group.

For this reason, we try to make an assessment of the main features of five countries from CEE and to establish through a preliminary analysis if using panel modelling is a proper method for estimating money demand in a future research, considering that there are some common patterns of monetary aggregates development.

Some examples of authors that employed samples of data covering emerging or transition economies from Europe are: Bahmani and Kutan [3], Bahmani-Oskooee, Kutan, Xi [4] and Fidrmuc [5]. They all implied data availability as one of the main determinants for selecting the countries in the sample. Using panel cointegration methods, Fidrmuc [5] studied the experience of six European countries (Czech Republic, Hungary, Poland,
Romania, Slovakia, Slovenia) during the accession to the European Union, taking into consideration the role of inflation, exchange rate and euro area interest rate. Inflation targeting resulted into an appropriate monetary regime before the adoption of the euro, the results confirming also the importance of capital substitution in these countries, because the euro area interest rate had a significant impact on money demand. As for the exchange rate, the estimated elasticity is relatively low, fact that implies the less important role played by currency substitution in these countries. Money demand was determined to be stable in a sample of seven Eastern European countries (namely: Armenia, Bulgaria, Czech Republic, Hungary, Poland, Russia, Slovak Republic), the estimations of Bahmani and Kutan [3] enforcing the statement that a monetary policy based on a broader measure of money plays an important role in the stabilization of the economic stability. The authors draw three major implications: (i) the market based monetary policy is still effective during the transition from a command economy to a market-based economy; (ii) as money demand is stable, a regime based on inflation targeting is feasible to meet the Maastricht criteria; (iii) the elasticity of independent variables (the determinants) taken into consideration in the equation are larger in these emerging markets, because money demand transactions associated with reforms play a bigger role.

In the same sample of countries, the economic and monetary uncertainty had significant short-run effects on the quantity of money from 1995 to 2010 [4]. However, both measures of uncertainty have a greater impact in the short-run than in the long-run in most of the countries, the results confirming that uncertainty doesn't exert adverse long-run effects on monetary equilibrium.

In a recent study, Dabrowski et al. [6] studied the causal relationship between nominal exchange rates and monetary fundamentals in CEE countries, and found strong evidence of causality running from monetary fundamentals to the exchange rate in some countries. This proves that the stock of money can provide useful information about the evolution of 
the exchange rates in the future. Ca'Zorzi et al. [7], using the experience of some major emerging markets from Asia, Central and Eastern Europe and Latin America, confirm the existence of a positive relationship between exchange rate pass-through and inflation in the analyzed countries. The importance of exchange rates for monetary policy is explained by Taylor [8] who considers exchange rate as a part of the transmission mechanism. Useful information are brought in the macroeconomic models by including exchange rates, because they relate the interest rate in one country to the interest rates in other countries, via the expected rate of appreciation.

The existence of differences in comparative price levels between CEE countries and EU countries is considered to be a possible source of inflationary pressures in the first category, Backé et al. [9] showing the existence of a correlation between relative price levels and inflation rates. They have concluded that CEE countries with low comparative price levels will tend to register greater inflation rates than countries with higher comparative price levels.

The income elasticity of money demand in transition economies was determined to be above unity, proving the wealth effect that income has on money demand. For example, in the case of the ten countries that joined the European Union in May 2004, the value of this coefficient was estimated on real data and was obtained a value of around 1.7 [10], being also a sign of a declining trend in velocity.

The studies that approach the idea of money demand modelling use the following standard theoretical form of the money demand function [11]: $\quad M^{D} / P=f\left(y, w, R_{M}^{*}, R_{B}^{*}, R_{E}^{*}, U\right)$, where $\mathrm{M}^{\mathrm{D}}$ is a measure for nominal money, $\mathrm{P}$ is the price index, $y$ is a scale variable representing the income (in general being used real GDP for encompassing this measure), w quantifies wealth, $R_{M}^{*}$ is the expected return on money, and $R_{B}^{*}, R_{E}^{*}$ are variables that quantify the opportunity cost of holding money (or, in other words, the expected return on assets other than money). According to the theoretical view, the income and wealth should have a positive effect on money demand, while the opportunity cost should care a negative coefficient, as it measures the lost earnings from alternative assets.

Starting from this function, in the next section we will include in our analysis the traditional variables that influence the demand for money. Moreover, as a result of the features of monetary variables in CEE countries, we will try to suggest some other additional variables that may influence the evolution of money demand in the countries included in our sample.

\section{Data Description}

The present analysis uses quarterly data from five Central and Eastern European countries, covering a period between 2000 and 2015 . The list of countries include: Bulgaria, Czech Republic, Hungary, Poland and Romania. The variables included into analysis are: narrow money (M1) and broad money (M2), the inflation rate (computed based on Consumer Price Index-CPI), real gross domestic product-GDP and real effective exchange rates. The choice of inflation rate and exchange rate for quantifying the opportunity cost of holding money is dictated by the fact that the inflation rate is considered to have a greater impact on money demand in the countries that pass through a transition period (see [2, p. 91]).

For the monetary aggregates, we chose to include two measures (M1 and M2) in order to determine if we can find a clear pattern in data regarding their volatility. Moreover, the stability of money demand function is influenced by the monetary series included in the estimation, as empirical studies confirm a greater stability of money demand when M2 monetary aggregate is used (see, for instance, [12] and [13]).

All data come from IFS (International Financial Statistics) database of the International Monetary Fund (IMF) and Eurostat database. The variables: real money-M1, real moneyM2, real GDP were seasonally adjusted and converted into logarithms. A detailed description of the variables is available in Appendix 1 . 
4 Monetary Features of the CEE Countries Maintaining price stability is the objective that stays at the basis of the monetary policy strategy adopted in each country from our sample (see Appendix 2). The results presented in the European Central Bank Convergence Report from June 2016 [14] indicate that in all the five countries the existing set of laws does not give full independence of the central bank, a fact that puts obstacles for policymakers in their attempt to enhance economic stability. The monetary policy strategy is based on direct inflation targeting in Czech Republic (since 1998), Hungary (since 2001), Poland (since 1998) and Romania (since 2005). The target for the inflation rate is publicly announced in advance and seeks at maintaining the value of the CPI around the announced value, allowing for a fluctuation within a band of 1 percentage point in either directions. The effectiveness of this strategy is supported by an exchange rate regime based on free floating (in Hungary and Poland) and managed floating (in Czech Republic and Romania). Bulgaria is under a currency board arrangement from 1997, this monetary policy regime assuring price stability, the exchange rate being fixed at 1.95583levs per euro starting from 2007. In neither country the national currency does not participates to Exchange Rate Mechanism II.

The monetary authority from all these states recognized the importance of a low and stable inflation rate in the medium and long term. As it may be observed from the Fig. 1, this objective was achieved differently and in different time spans in the case of the five countries. Among all, Romania represented a particular case, the inflation rate (based on HCIP-Harmonised Index of Consumer Prices) registering three-digit values at the beginning of the 1990s. Two digit values for the inflation rate were registered at the beginning of the analyzed period in: Bulgaria, Hungary or Poland; while the best performance, among the analyzed countries, in maintaining the inflation rate at a low and stable value in the medium term is visible in Czech Republic.

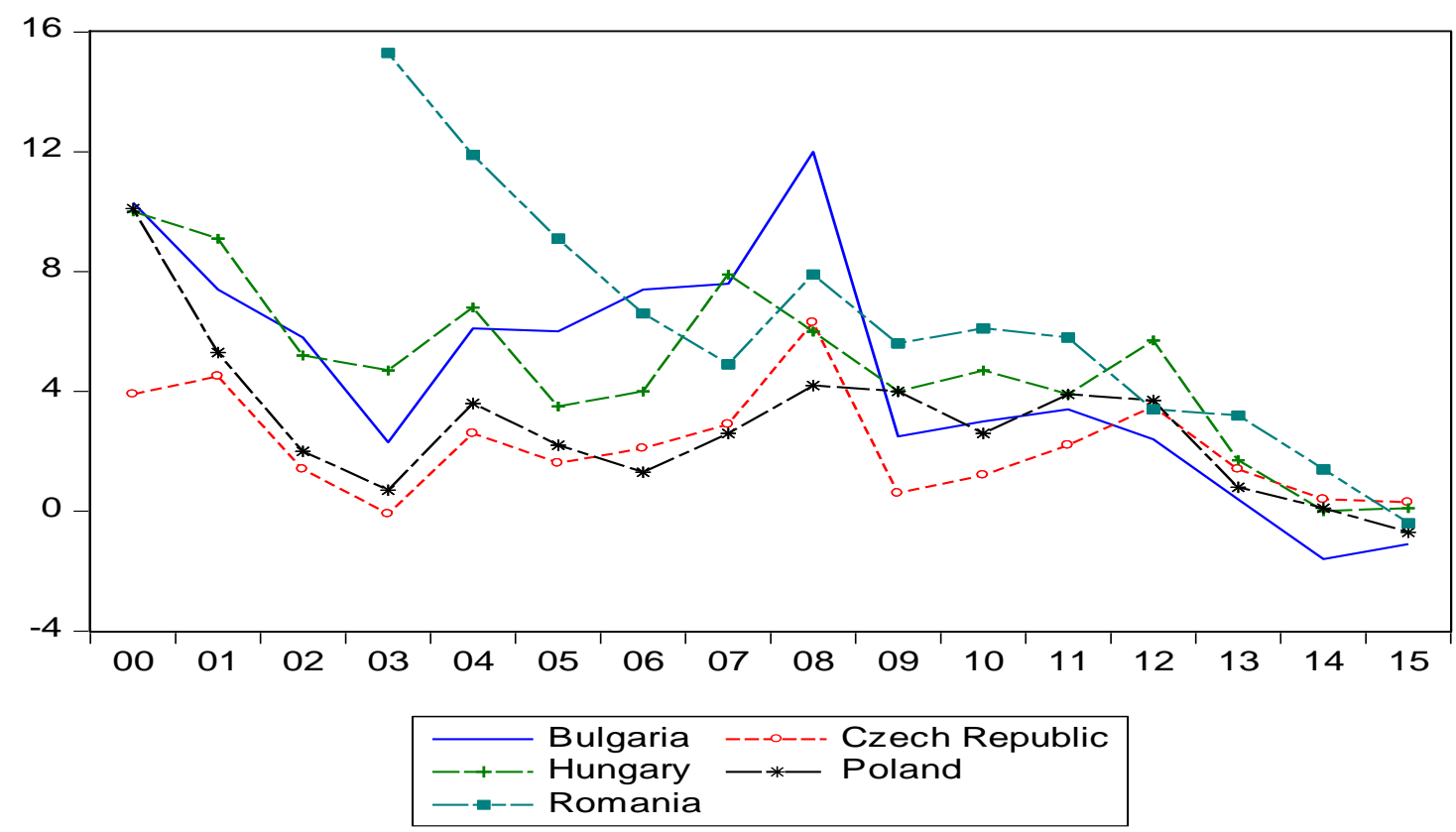

Fig. 1. Inflation rate (based on HCPI) in CEE countries

Note: In the figure are reported the values of HCPI-Harmonised Consumer Price Index $(2015=100)$ - annual data (average index and rate of change). For a proper representation, in the case of Romania, data are reported in the graph starting only with 2003 when the inflation rate decreased below 20 percent.

Source: author's computation based on data from Eurostat database, accessed on 26.08.2016.

The evolution of the individual time series for two measures of money (namely: narrow
money-M1 and broad money-M2) can be seen in Fig. 2 for each country individually. The 
evolution of the two series from 2000 to 2015 is very similar in the case of Czech Republic and Poland, the increase in M2 being influenced mainly by an increase in the demand for narrow money. In Hungary it can be observed that liquid assets, other than currency in circulation and overnight deposits, represent a higher share in M2. As for Bulgaria and Romania is visible an increasing trend in M2.
This trend is dictated mainly by the increase in deposits with agreed maturity up to two years and deposits redeemable at notice up to three months in the case on Bulgaria. In Romania the increasing trend was influenced by the increase in time, saving deposits and foreign currency deposits of resident non-bank non-central government sectors with banking institutions and banks in liquidation.
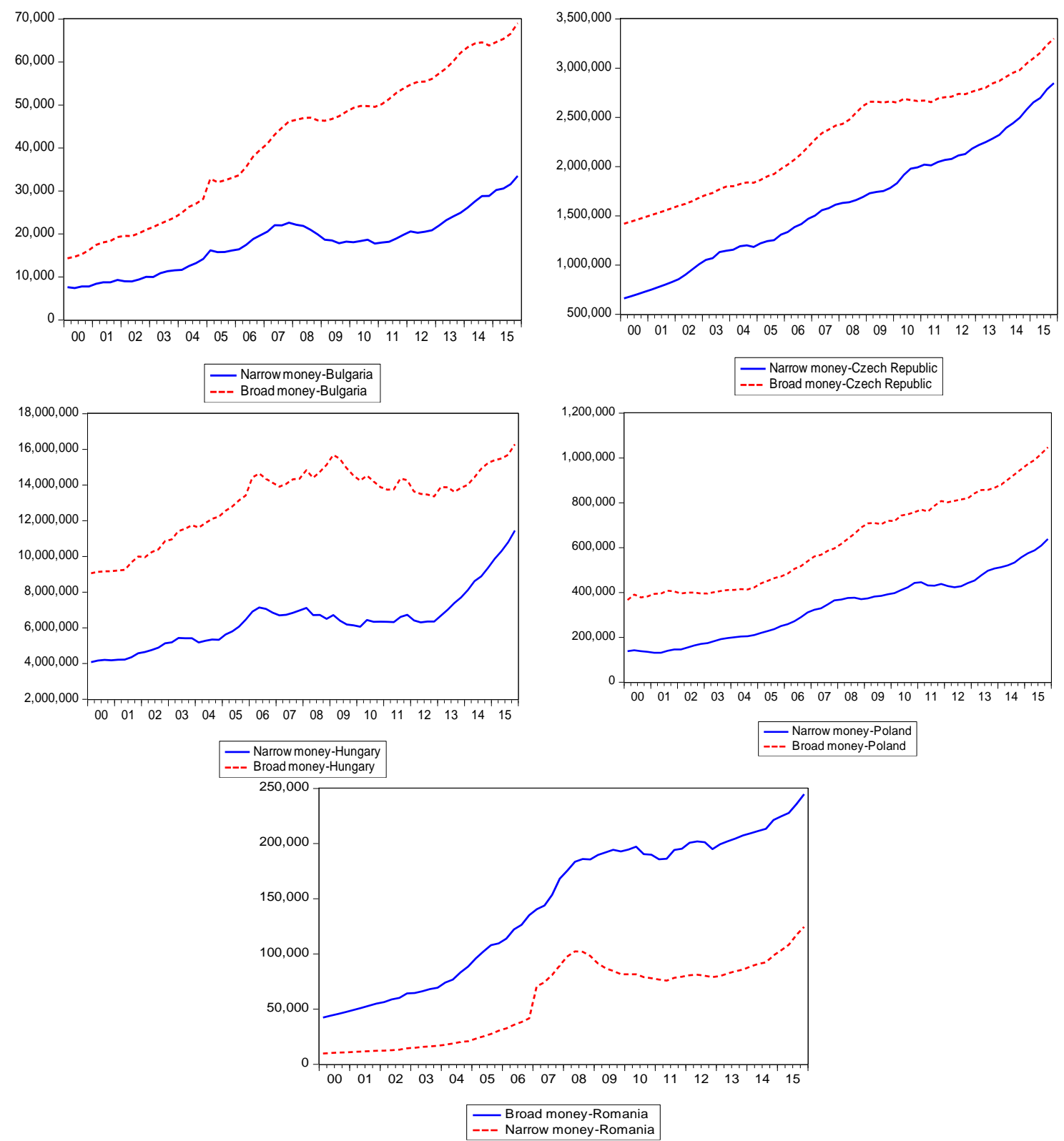

Fig. 2. Real narrow money and real broad money evolution in CEE countries, 2000-2015 Note: Data are expressed in millions of national currency. National definitions of monetary aggregates are used. Source: International Financial Statistics of the IMF (2016), own representation.

As it is observable from a comparative analysis based on monetary variables evolution and the evolution of the inflation rate, it can be drawn the conclusion that, for this sample of countries, the monetary variables seem to be influenced by inflation or, more precisely, by the disinflationary process. Therefore, a stable and predictable inflation rate increases the 
confidence of the public in the central bank decisions, and generates an increase in the demand for money, as the opportunity cost represented by inflation reduces. The evolution of the real effective exchange rate data series (not reported here graphically) also reveals high volatility of prices of tradable and nontradable goods, between 2000 and 2015.

The evolution of the aggregate demand is also a leading factor for explaining the evolution of the demand for money. The scale variable included in the money demand function quantifies this aspect, as it tries to encompass the change in money demand dictated by an increase in income or wealth. We choose to proxy here the income by the real gross domestic product. As Fig. 3 reveals, the GDP has increased in real terms in all countries except for the period of the global economic and financial crisis: 2008-2010. However, Poland experienced only a slow downturn even in the years of crisis, in comparison with the other countries, for which the recovery lasted for several years. The propagation of the international shock and its lasting effects support the hypothesis that international spillovers still play an important role in economies in transition. This observation is based on the observed evolution of their real GDP in the years coming right after the onset of the crisis.

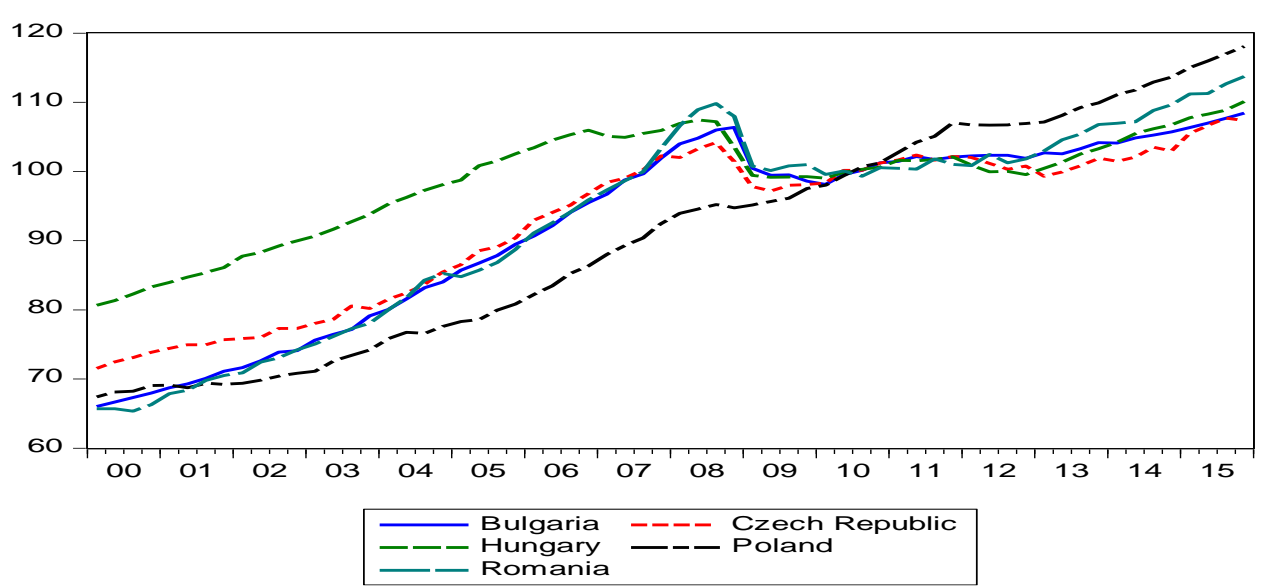

Fig. 3. Real GDP growth, 2000-2015

Source: International Financial Statistics of the IMF (2016), own representation.

In spite of the similarities of these economies regarding their economic past, the characteristics of their own financial markets influenced in certain measure the path of the economy. If, for example, we take a look on monetization (computed as the share of broad money-M2 in GDP), an indicator considered as a benchmark for financial deepening, we can observe that at the beginning of the 1990s, all countries experienced a decline in monetization, followed by an upward trend. While in Bulgaria and Czech Republic, the value of monetization exceed $70 \%-80 \%$ in 2014 , in comparison in Hungary and Poland the value remained around $60 \%$. In the case of Romania monetization fluctuated barely within a $10 \%$ band in the last twenty years, and the value remains the lowest from the countries in our sample, not exceeding $40 \%$ in 2014.
Over the last two decades, in all the countries from our sample were implemented structural changes in the monetary policy regime, changes that aimed either the control over the exchange rate or the inflation rate. The role of the monetary authority was increasing, as they had not only to manage all this changes, but also to increase the transparency of the adopted measures. However, this task was not an easy one, as economic agents and the population have perceived all the changes as an increase instability of the financial sector. All these changes, in conjunction with relatively high rates of inflation lead to an increase in dollarization. As the economic agents perceive the instability of the economy as a threat for their purchasing power, they have the tendency to use foreign currencies to store their assets. 
The dollarization is therefore a widespread phenomenon in transition and emerging economy, one important feature of this process being the fact that the flux of foreign capital in continuously increasing, and that leads to an increase in credit dollarization and a decrease in deposit dollarization [15]. Marcelin and Mathur [16] tried to assess which are the effects of financial dollarization on financial development in the emerging markets. They explain that dollarization increases the demand for foreign currency and, in the presence of some limitations to crediting in foreign currencies, may lead to a decrease in investment projects and further to a lower GDP, greater budget deficits and weaker domestic currency. Levy-Yeyati, [17] also states that financial dollarization can also lead to: an increase in the variability of money demand, greater financial fragility and a slower and more volatile growth. If we take into consideration the countries from Central and Eastern Europe, real data revealed that euro convergence was preceded by financial dollarization and, at the beginning of 2000s, euro was only gradually becoming a driving factor [17].

Recent data on indicators that describe the widespread of this phenomenon, reveal the existence of a high degree of substitution of the local currency with foreign currencies in CEE countries. In the Table 1, is represented the degree of dollarization for the countries in our sample and also for a set of countries that are members of the Euro Area, form the Baltic Region (Estonia, Latvia and Lithuania) and from Central and Eastern Europe (Slovak Republic and Slovenia) in order to make a comparison with countries from the same region. We used as a proxy for measuring the financial dollarization data on: foreign-currencydenominated loans and foreign-currency-denominated liabilities as a percentage of total loans or liabilities. The variables are taken from International Financial Statistics (IFS) database for the most recent available period.

Table 1. Dollarization in the CEE countries

\begin{tabular}{c|lrrr}
\hline & Country & $\begin{array}{l}\text { FC denominated } \\
\text { loans/ total loans }\end{array}$ & $\begin{array}{l}\text { FC denominated } \\
\text { total liabilities }\end{array}$ & liabilities/ \\
\hline \multirow{3}{*}{$\begin{array}{c}\text { Euro Area } \\
\text { Countries }\end{array}$} & Estonia & 1.2 & - \\
& Latvia & 27.7 & 40.4 \\
& Lithuania & - & - \\
& Slovak Republic & 1.8 & 3.8 \\
& Slovenia & - & - \\
\hline \multirow{3}{*}{$\begin{array}{c}\text { Non-Euro Area } \\
\text { countries }\end{array}$} & Bulgaria & Czech Republic & 57.0 & 49.0 \\
& Hungary & - & - \\
& Poland & - & 19.3 \\
& Romania & 27.8 & 35.0 \\
\hline
\end{tabular}

Note: Data are reported in percentage. The symbol (-) indicates a lack of statistical data. Data are reported for 2016Q1 for all countries except for: Slovenia (2015Q4), Bulgaria (2014Q1), Lithuania (2015Q4) and Romania (2015Q3).

Source: Financial Soundness Indicators (FSI) from International Financial Statistics (IFS) database, accessed on 18 August 2016

The high values observed especially in the countries that are not members of the Euro Area, are correlated with the observation of Asel [18] for Central Asia, that countries with a smaller banking system are more dollarized than those in which the banking system is more developed. The effectiveness of the monetary policy can therefore be influenced by the fact that in these countries are used foreign currencies as means of payment and store of value. Marcelin and Mathur [16] point out the fact that even money supply is affected by dollarization, by inflows of portfolio adjustment, remittances and the behavior of economic agents that hold assets denominated in a foreign currency. 
The central bank is also recognized in the literature as playing a decisive role in influencing the general economic performance through monetary policy [19], [20], [21]. With respect to money demand, this effect is materializes through the effects of the transparency of the process of monetary policy implementation. The perception and the level of understanding of economic agents may influence the outcome of the decisions adopted by monetary authorities. The independence of a central bank and its commitment on the long-term increases the confidence of the public, and makes the transmission mechanism more effective.

Based on all the above observed evolution of the variables that are considered in the literature as determinants of money demand, in the last part of the analysis we move to a more integrated approach. Therefore we try to see which are the preliminary characteristics of the time series for all the variables considered. This approach is supported by the motivation of investigating the nature of the relationship between money demand and its determinants, and identifying the existence of some possible causal relations between them. A stable and predictable relationship in the long term between money demand and its determinants is possible only if the variables are long-term cointegrated, so they move together in time. Thus, in this preliminary work, we test only for the stationarity of the series. Augmented Dickey-Fuller and Phillips-Perron unit root tests are used for the series in levels and also in first differences (see Appendix 3). We employ the same exercise for each country individually. The results are reported using a 5\% significance level, if it is not specified otherwise in the tables. The overall results indicate that all the series are I(1), so they are stationary in first differences. In testing the existence of co-integration and the causal relationships between the variables we will rely on this findings.

\section{Conclusions}

As money demand is an important issue for policymakers when they decide on the mone- tary policy instruments they should use in order to reach the targeted rate of inflation, the stability of this function is a necessary condition in order to provide reliable information on the evolution of monetary variables. Moreover is useful to assess a priori which are the main determinants of the evolution of money demand and how strong is their impact, in order to foresee the outcome of a monetary policy decision.

In this paper, we address the topic of money demand using the experience of five Central and Eastern European countries that are members of the European Union, but have not already adopted the single currency. The main goal was to establish common patterns between the evolution of monetary aggregates and their determinants in order to see if it is reliable to test, in a future research, for the stability of money demand in a panel framework using this sample of data. The analytical analysis reveals the existence of some similarities between the goals of their monetary policies, but the instruments used in order to assess these objectives have some individual characteristics also. We may mention, in this regard, the strategy of monetary policy adopted (based on inflation targeting or exchange rate). However, their economic and historic conditions are supportive for the idea of treating them as a group, as they passed through economic and financial reforms in the past in order to become candidates for joining the euro area.

As future research goals on this topic we take into consideration the idea of testing the stability of money demand on the long run. In the estimations we should include variables whose evolution was described in this paper, namely: the level of income, the degree of monetization, the inflation rate or the exchange rate. The function of money demand will be also extended in terms of inputs with variables that may have a significant impact in this particular set of countries, such as: the influence of the euro area interest rate, the development of the financial sector or the central bank's independence, which were analyzed from the perspective of their evolution common patterns. 


\section{References}

[1] P. Foresti, O. Napolitano, „Modelling long-run money demand: a panel data analysis on nine developed economies," Applied Financial Economics, vol. 23, no. 22, pp. 1707-1719, 2013.

[2] S. Ghatak, J. R. Sánchez-Fung, Monetary Economics in Developing Countries, China: Third Edition, Palgrave Macmillan, 2007, p. 91.

[3] S. Bahmani, A. M. Kutan, „How stable is the demand for money in the emerging economies?," Applied Economics, vol. 42, pp. 3307-3318, DOI: 10.1080/00036840802112406, 2010.

[4] M. Bahmani-Oskooee, A. M. Kutan și D. $\mathrm{Xi}$, ,The impact of economic and monetary uncertainty on the demand for money in emerging economies," Applied Economics, vol. 45:23, pp. 3278-3287, DOI: 10.1080/00036846.2012.705430, 2013.

[5] J. Fidrmuc, „Money demand and disinflation in selected CEECs during the accession to the EU," Applied Economics, vol. 41, pp. 1259-1267, DOI: 10.1080/00036840601019323, 2009.

[6] M. A. Dabrowski, M. Papiez and S. Śmiech, „Causal relations between nominal exchange rates and monetary fundamentals in Central and Eastern European countries," Economics of Transition, vol. 23(1), pp. 45-73, DOI : 10.1111/ecot.12055, 2015.

[7] M. Ca'Zorzi, E. Hahn and M. Sánchez, „Exchange Rate Pass-Through in Emerging Markets," European Central Bank Working Paper Series, vol. No 739/March 2007, 2007.

[8] J. B. Taylor, „, The Role of the Exchange Rate in Monetary-Policy Rules," The American Economic Review, Papers and Proceedings of the Hundred Thirteenth Annual Meeting of the American Economic Association (May, 2001), vol. 91, no. 2, pp. 263-267, 2001.

[9] P. Backé, J. Fidrmuc, T. Reininger and F. Schardax, ,Price Dynamics in Central and Eastern European EU Accession Countries," Emerging Markets Finance and
Trade, vol. 39:3, pp. 42-78, http://dx.doi.org/10.1080/1540496X.2003 .11052541, 2003.

[10] C. Dreger, H. E. Reimers and B. Roffia, „Long-Run Money Demand in the New EU Member States with Exchange Rate Effects," European Central Bank Working Paper Series, vol. 628/May 2006, 2006.

[11] M. Friedman, „Quantity Theory of Money," In The New Palgrave: A Dictionary of Economics, edited by John Eatwell, Murray Milgate, and Peter Newman. New York: Stockton Press; and London: Macmillan, 1987, vol. 4, pp. 3-20, 1987.

[12] R. L. Hetzel and Y. P. Mehra, „The Behaviour of Money Demand in the 1980s," Journal of Money, Credit and Banking, vol. 21 , no. 4 , p. DOI: $10.2307 / 1992353$, 1989.

[13] P. Foresti and O. Napolitano, „Money Demand in the Eurozone: Do Monetary Aggregates Matter?," Inzinerine Ekonomika-Engineering Economics, vol. 25, no. 5, pp. 497-503, http://dx.doi.org/10.5755/j01.ee.25.5.381 0, 2014.

[14] „European Central Bank Convergence Report," available online at: https://www.ecb.europa.eu/pub/pdf/conrep/cr201606.en.pdf?a91977931874a7c6 c63d80305b651394, accessed on $06 \mathrm{Au}-$ gust 2016, June 2016.

[15] H. Basso, O. Calvo-Gonzalez and M. Jurgilas, „Financial dollarization: The role of foreign-owned banks and interest rates," Journal of Banking\& Finance, vol. 35, no. doi:10.1016/j.jbankfin.2010.11.018, pp. 794-806, 2011.

[16] I. Marcelin and I. Mathur, „Financial sector development and dollarization in emerging economies," International Review of Financial Analysis, vol. 46, http://dx.doi.org/10.1016/j.irfa.2016.04.0 10, pp. 20-32, 2016.

[17] E. Levy-Yeyati, „Financial Dollarization: Evaluating the Consequences," Economic Policy, vol. 21, no. 45, pp. 61+63-118, 2006.

[18] I. Asel, „Financial Sector Development and Dollarization in the Economies of 
Central Asia," Final Report, Grant No. RRC IX-69, available online at: https://www.cerge-

ei.cz/pdf/gdn/rrc/RRCIX_69_paper_01.pdf, accessed on 18.08.2016, 2010.

[19] B. Bernanke, ,Monetary policy and the housing bubble," in Remarks at the American Economic Association Annual Conference, Atlanta, Georgia, available online at: http://www.federalreserve.gov/newsevents/speech/bernanke20 100103a.pdf, accessed on 21 June 2016, 2010.
[20] O. Blanchard, G. Dell'Aricca and P. Mauro, ,Rethinking macroeconomic policy, IMF staff position note, International Monetary Fund, Washington, D.C.," Journal of Money, Credit and Banking, vol. 42(s1), available online at: http://onlinelibrary.wiley.com/doi/10.1111/j.15384616.2010.00334.x/epdf, accessed on 21 June 2016, pp. 199-215, 2010.

[21] J. Taylor, ,,The Effectiveness of Central Bank Independence vs. Policy Rules," Business Economics, National Association for Business Economics, vol. 48, no. 3, 2013.

\section{Appendix 1}

\begin{tabular}{|c|c|c|c|}
\hline Variable name & Definition & Units & Source \\
\hline $\begin{array}{l}\text { Log (Real } \\
\text { money -M1) }\end{array}$ & $\begin{array}{l}\text { Money supply measured by real M2. } \\
\text { Nominal M2 values, taken from IFS, are } \\
\text { then deflated by Consumer Price Index. } \\
\text { The variable is expressed in millions, na- } \\
\text { tional definitions of monetary aggregates } \\
\text { being used. }\end{array}$ & $\begin{array}{l}\text { Millions of na- } \\
\text { tional currency } \\
\text { (constant prices) }\end{array}$ & IFS \\
\hline $\begin{array}{l}\text { Log (Real } \\
\text { money -M2) }\end{array}$ & $\begin{array}{l}\text { Money supply measured by real M1. } \\
\text { Nominal M1 values, taken from IFS, are } \\
\text { then deflated by Consumer Price Index. } \\
\text { The variable is expressed in millions, na- } \\
\text { tional definitions of monetary aggregates } \\
\text { being used. }\end{array}$ & $\begin{array}{l}\text { Millions of na- } \\
\text { tional currency } \\
\text { (constant prices) }\end{array}$ & IFS \\
\hline $\log ($ real GDP) & Real gross domestic product & $\begin{array}{c}\text { Index } \\
(2010=100)\end{array}$ & IFS \\
\hline $\log (\mathrm{CPI})$ & Consumer Price Index & $\begin{array}{c}\text { Index } \\
(2010=100)\end{array}$ & IFS \\
\hline $\log (\mathrm{REER})$ & $\begin{array}{l}\text { Real Effective Exchange Rate, based on } \\
\text { Consumer Price Index }\end{array}$ & $\begin{array}{c}\text { Index } \\
(2010=100)\end{array}$ & IFS \\
\hline
\end{tabular}

Appendix 2

\begin{tabular}{|l|l|l|l|}
\hline Country & Currency & $\begin{array}{l}\text { EU member } \\
\text { since }\end{array}$ & Monetary policy regime \\
\hline BULGARIA & $\begin{array}{l}\text { Bulgarian lev } \\
\text { BGN }\end{array}$ & 01.01 .2007 & $\begin{array}{l}\text { Currency board arrangement; The Bul- } \\
\text { garian LEV did not participate to ERM II, } \\
\text { the exchange rate is fixed at: 1.95583 levs } \\
\text { per euro }\end{array}$ \\
\hline $\begin{array}{l}\text { CZECH RE- } \\
\text { PUBLIC }\end{array}$ & $\begin{array}{l}\text { Czech koruna } \\
\text { CZK }\end{array}$ & 01.05 .2004 & $\begin{array}{l}\text { Direct inflation targeting (since 1998); } \\
\text { The Hungarian Forint did not participate } \\
\text { to ERM II; flexible exchange rate regime }\end{array}$ \\
\hline
\end{tabular}




\begin{tabular}{|l|l|l|l|}
\hline HUNGARY & $\begin{array}{l}\text { Hungarian } \\
\text { forint HUF }\end{array}$ & 01.05 .2004 & $\begin{array}{l}\text { Inflation targeting system (since June } \\
\text { 2001); The Hungarian Forint did not par- } \\
\text { ticipate to ERM II; flexible exchange rate } \\
\text { regime }\end{array}$ \\
\hline POLAND & $\begin{array}{l}\text { Polish zloty } \\
\text { PLN }\end{array}$ & 01.05 .2004 & $\begin{array}{l}\text { Direct inflation targeting (since 1998); } \\
\text { The Polish Zloty did not participate to } \\
\text { ERM II; flexible exchange rate regime }\end{array}$ \\
\hline ROMANIA & $\begin{array}{l}\text { Romanian leu } \\
\text { RON }\end{array}$ & 01.01 .2007 & $\begin{array}{l}\text { Direct inflation targeting (since 2005); } \\
\text { The Romanian Leu did not participate to } \\
\text { ERM II; flexible exchange rate regime: } \\
\text { managed floating of the exchange rate }\end{array}$ \\
\hline
\end{tabular}

\section{Appendix 3- Unit root tests}

Note. The results of the unit root tests are reported at 5\% significance level if is not specified otherwise. One $*$ means $10 \%$ significance level.

\begin{tabular}{|l|c|c|c|c|}
\hline \multicolumn{3}{|c|}{ Bulgaria } \\
\hline & \multicolumn{3}{|c|}{ Level } & \multicolumn{2}{c|}{ First difference } \\
\cline { 2 - 5 } & ADF & Phillips-Perron & ADF & Phillips-Perron \\
\hline Log (real_m1_sa) & $\mathrm{I}(1)$ & $\mathrm{I}(1)$ & $\mathrm{I}(0)$ & $\mathrm{I}(0)$ \\
\hline Log (real_m2_sa) & $\mathrm{I}(1)$ & $\mathrm{I}(1)$ & $\mathrm{I}(0)$ & $\mathrm{I}(0)$ \\
\hline Log (reer) & $\mathrm{I}(1)$ & $\mathrm{I}(1)$ & $\mathrm{I}(0)$ & $\mathrm{I}(0)$ \\
\hline Log (cpi_sa) & $\mathrm{I}(1)$ & $\mathrm{I}(1)$ & $\mathrm{I}(0)$ & $\mathrm{I}(0)$ \\
\hline Log (gdpr_sa) & $\mathrm{I}(1)$ & $\mathrm{I}(1)$ & $\mathrm{I}(0)$ & $\mathrm{I}(0)$ \\
\hline
\end{tabular}

\begin{tabular}{|l|c|c|c|c|}
\hline \multicolumn{4}{|c|}{ Czech Republic } \\
\hline & \multicolumn{2}{|c|}{ Level } & \multicolumn{2}{c|}{ First difference } \\
\cline { 2 - 5 } & ADF & Phillips-Perron & ADF & Phillips-Perron \\
\hline Log (real_m1_sa) & $\mathrm{I}(1)$ & $\mathrm{I}(1)$ & $\mathrm{I}(0)$ & $\mathrm{I}(0)$ \\
\hline Log(real_m2_sa) & $\mathrm{I}(1)$ & $\mathrm{I}(1)$ & $\mathrm{I}(0)$ & $\mathrm{I}(0)$ \\
\hline Log (reer) & $\mathrm{I}(1)$ & $\mathrm{I}(1)$ & $\mathrm{I}(0)$ & $\mathrm{I}(0)$ \\
\hline Log (cpi_sa) & $\mathrm{I}(1)$ & $\mathrm{I}(1)$ & $\mathrm{I}(0)$ & $\mathrm{I}(0)$ \\
\hline Log (gdpr_sa) & $\mathrm{I}(1)$ & $\mathrm{I}(1)$ & $\mathrm{I}(0)$ & $\mathrm{I}(0)$ \\
\hline
\end{tabular}

\begin{tabular}{|l|c|c|c|c|}
\hline \multicolumn{4}{|c|}{ Hungary } \\
\hline & \multicolumn{2}{|c|}{ Level } & \multicolumn{2}{c|}{ First difference } \\
\cline { 2 - 5 } & ADF & Phillips-Perron & ADF & Phillips-Perron \\
\hline Log (real_m1_sa) & $\mathrm{I}(1)$ & $\mathrm{I}(1)$ & $\mathrm{I}(0)$ & $\mathrm{I}(0)$ \\
\hline Log (real_m2_sa) & $\mathrm{I}(1)$ & $\mathrm{I}(1)$ & $\mathrm{I}(0)$ & $\mathrm{I}(0)$ \\
\hline Log (reer) & $\mathrm{I}(0)^{*}$ & $\mathrm{I}(0)^{*}$ & $\mathrm{I}(0)$ & $\mathrm{I}(0)$ \\
\hline $\log$ (cpi_sa) & $\mathrm{I}(1)$ & $\mathrm{I}(1)$ & $\mathrm{I}(0)$ & $\mathrm{I}(0)^{*}$ \\
\hline Log (gdpr_sa) & $\mathrm{I}(1)$ & $\mathrm{I}(1)$ & $\mathrm{I}(0)$ & $\mathrm{I}(0)$ \\
\hline
\end{tabular}

\begin{tabular}{|l|c|c|c|c|}
\hline \multicolumn{4}{|c|}{ Poland } \\
\hline & \multicolumn{2}{|c|}{ Level } & \multicolumn{2}{c|}{ First difference } \\
\cline { 2 - 5 } & ADF & Phillips-Perron & ADF & Phillips-Perron \\
\hline Log (real_m1_sa) & $\mathrm{I}(1)$ & $\mathrm{I}(1)$ & $\mathrm{I}(0)$ & $\mathrm{I}(0)$ \\
\hline Log(real_m2_sa) & $\mathrm{I}(1)$ & $\mathrm{I}(1)$ & $\mathrm{I}(0)$ & $\mathrm{I}(0)$ \\
\hline
\end{tabular}




\begin{tabular}{|l|c|c|c|c|}
\hline $\log ($ reer) & $\mathrm{I}(0)^{*}$ & $\mathrm{I}(1)$ & $\mathrm{I}(0)$ & $\mathrm{I}(0)$ \\
\hline Log (cpi_sa) & $\mathrm{I}(1)$ & $\mathrm{I}(1)$ & $\mathrm{I}(1)$ & $\mathrm{I}(1)$ \\
\hline Log $\left(\mathrm{gdpr} \_s a\right)$ & $\mathrm{I}(1)$ & $\mathrm{I}(1)$ & $\mathrm{I}(0)$ & $\mathrm{I}(0)$ \\
\hline
\end{tabular}

\begin{tabular}{|l|c|c|c|c|}
\hline \multicolumn{4}{|c|}{ Romania } \\
\hline & \multicolumn{2}{|c|}{ Level } & \multicolumn{2}{c|}{ First difference } \\
\cline { 2 - 5 } & ADF & Phillips-Perron & ADF & Phillips-Perron \\
\hline Log (real_m1_sa) & $\mathrm{I}(1)$ & $\mathrm{I}(1)$ & $\mathrm{I}(0)$ & $\mathrm{I}(0)$ \\
\hline $\log$ (real_m2_sa) & $\mathrm{I}(1)$ & $\mathrm{I}(1)$ & $\mathrm{I}(0)$ & $\mathrm{I}(0)$ \\
\hline Log (reer) & $\mathrm{I}(1)$ & $\mathrm{I}(1)$ & $\mathrm{I}(0)$ & $\mathrm{I}(0)$ \\
\hline Log (cpi_sa) & $\mathrm{I}(0)$ & $\mathrm{I}(0)$ & $\mathrm{I}(0)$ & $\mathrm{I}(0)$ \\
\hline Log (gdpr_sa) & $\mathrm{I}(1)$ & $\mathrm{I}(1)$ & $\mathrm{I}(0)$ & $\mathrm{I}(0)$ \\
\hline
\end{tabular}

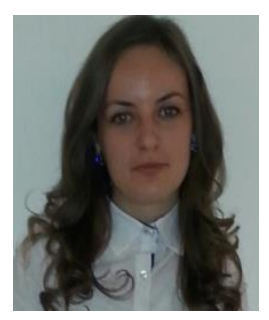

Valentina Ioana MERA has graduated the Faculty of Economics and Business Administration, Babeș-Bolyai University (UBB) from Cluj-Napoca in 2014. Currently she is a PhD candidate of the Doctoral School of Economics and Business Administration from Babeș-Bolyai University of Cluj-Napoca. In the meantime, she is Associate Teacher at the Department of Political Economy of Faculty of Economics and Business Administration from UBB, where she teaches seminars of Microeconomics and Macroeconomics. Her area of research focuses on monetary economics, macroeconomic policy and money demand. 